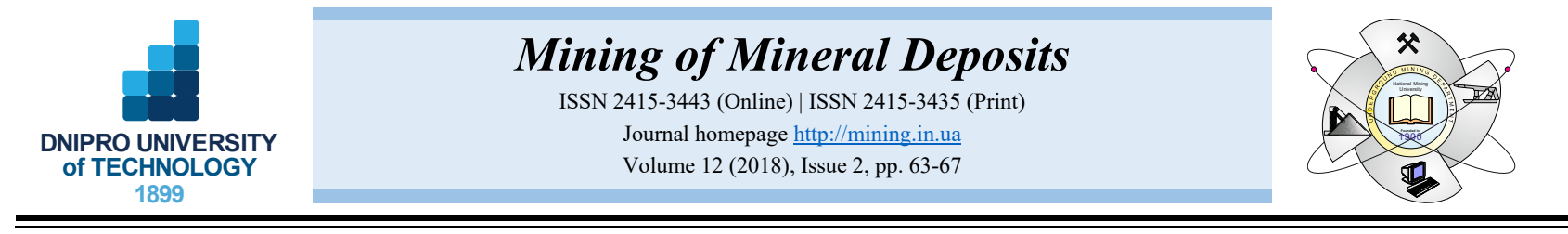

UDC 622.831 .6

https://doi.org/10.15407/mining12.02.063

\title{
PROGNOSIS OF SURFACE DEFORMATION BY THE INFLUENCE FUNCTION METHOD IN TERMS OF PAROSENI MINE (ROMANIA)
}

\author{
R.R. Marian ${ }^{1}$, D.P. Marian ${ }^{1 *}$ \\ ${ }^{1}$ University of Petrosani, Petrosani, Romania \\ *Corresponding author: e-mail dacianmarian@upet.ro, tel.+40748130633
}

\begin{abstract}
Purpose. The paper analyzes a problem of surface deformation as a result of low-inclined seam underground mining in Paroseni mine, Romania. Solving this problem makes it possible to predict the effects of the underground mining on the surface while offering the possibility of taking appropriate measures to protect the objects already available in the area or those to be built.

Methods. In order to analyze the behavior of the surface affected by underground mining of the coal seams in Paroseni mine, the influence function method was applied.

Findings. In the paper, the authors analyze how the underground mining acts on the surface in the case of the coal extraction in Paroseni mine, Jiu Valley, Romania. The possibility of important object placing in the area affected by the underground mining has also been analyzed.

Originality. The paper is an original case study; the results, presented by the authors, have been obtained while using the influence function method, a well-known and widely applied method for investigating the subsidence phenomenon.

Practical implications. The obtained results represent the prognosis of the surface deformation due to underground coal mining in Paroseni mine, Romania. These results were considered precise enough to determine the amount of surface deformation and the possibility of important object placing in the area affected by the extraction.
\end{abstract}

Keywords: underground mining, coal seams, prognosis, influence function, subsidence, horizontal displacement

\section{INTRODUCTION}

The need to study the phenomenon of surface deformation as a result of underground mining of useful mineral substances has emerged with the development of mining and, in particular, with the transition from extraction predominantly to the surface (open-pit mining) to underground mining (Ortelecan, 1997; Marian, 2011; Vereș, Marian, Fissgus, \& Ștefan, 2017).
The subsidence phenomenon is still being studied and will be studied in the future as it is a topical issue through the need to protect the surface and the constructions located in the area influenced by the underground mining (Onica \& Marian, 2012; Zhu et al., 2016; Taherynia, Fatemi Aghda, Ghazifard, \& Moradi, 2017).

The Paroseni mining perimeter (Fig. 1) is between the Lupeni perimeter to the west and the Vulcan perimeter to the east, in the region called Jiu Valley, Romania.

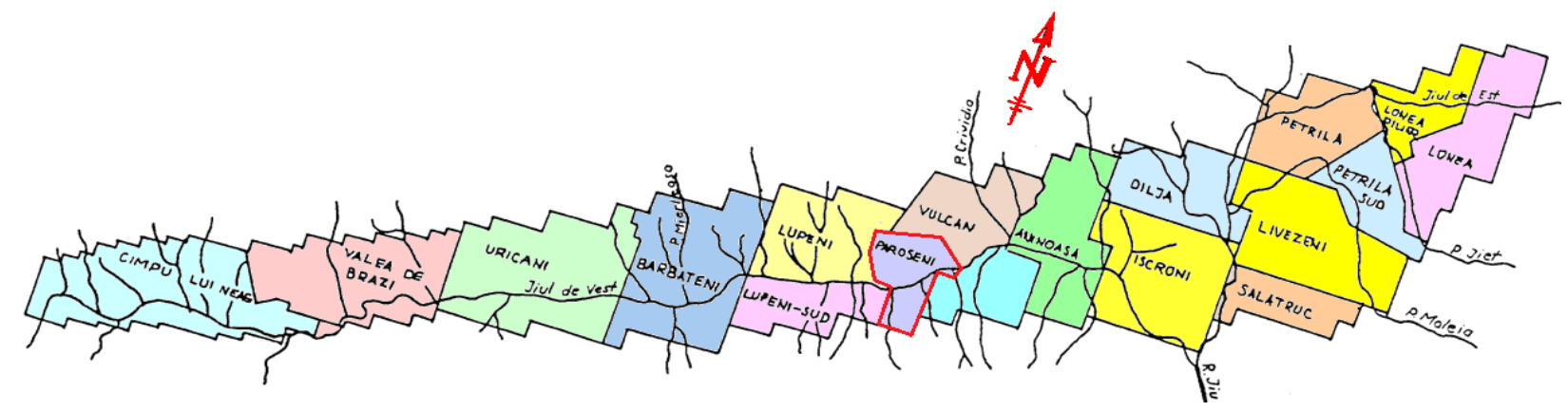

Figure 1. The mining perimeters from Jiu Valley, Romania

(C) 2018. R.R. Marian, D.P. Marian. Published by the Dnipro University of Technology on behalf of Mining of Mineral Deposits.

This is an Open Access article distributed under the terms of the Creative Commons Attribution License (http://creativecommons.org/licenses/by/4.0/),

which permits unrestricted reuse, distribution, and reproduction in any medium, provided the original work is properly cited. 
Underground mining of the coal seams from the Paroseni mining field has major implications regarding the stability of the surface and buildings.

Taking into account only the last 25 years (during this period coal seams No. 3 and 5 were extracted), the volume of the voids left after the extraction of coal at Paroseni mine is approx. $1700000 \mathrm{~m}^{3}$. The need to know the amount of surface displacement in the case of Paroseni mine is also important due to the fact that it is projected to build an important object which was initially designed to cross this mining field.

In order to analyze the surface deformation as a result of underground mining the influence function method was applied (Floarea, Marian, Onica, \& Cozma, 2015; Marian, Onica, Marian, \& Floarea, 2017).

The influence function methods (Fig. 2) are based on the prognosis of the surface deformation by means of the influence area theory around the point of extraction (Fissgus, 2011; Onica, Cozma, Marian, \& Ştefan, 2014; Marian, Onica, Marian, \& Floarea, 2017).

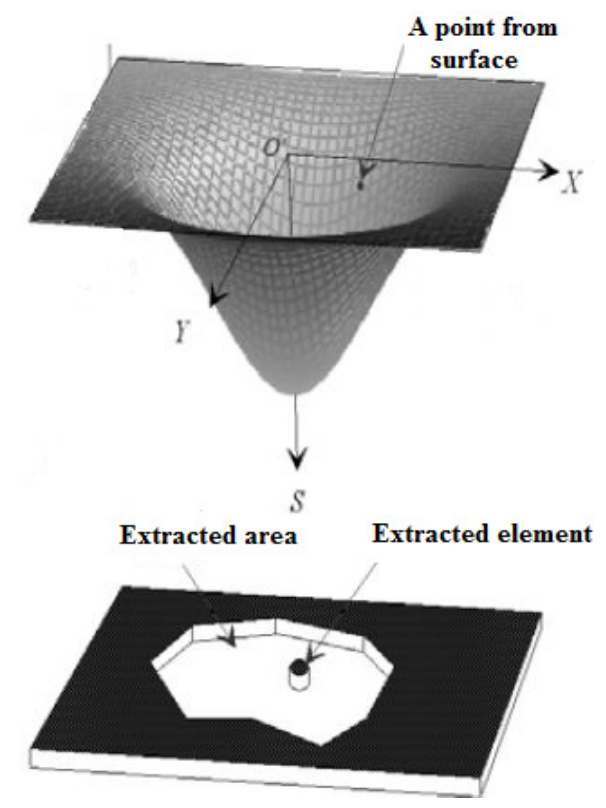

Figure 2. The influence function method theory

Different forms of influence functions were obtained by several researchers of subsidence including: Bals, Bayer, Saan, Knothe, Brauner etc. (Wei, Lu, Sun, \& Wei, 2007).

In the case described in this paper, for the surface subsidence prognosis due to underground mining, we applied the influence function developed by Knothe, also known as Knothe-Budryk method (Luo, Peng, \& Zhu, 2008):

$S(x, y)=\frac{S_{\max }}{R} \cdot \int_{x_{1}}^{x_{2}} \exp ^{\left[-\pi \cdot \frac{x^{2}+y^{2}}{R^{2}}\right]} \cdot d x$,

where:

$S_{\max }=m \cdot a-$ the maximum possible subsidence;

$m$ - the coal seam thickness;

$a$ - subsidence factor;

$R$ - the radius of principal influence;

$x$ - the coordinate of a point from the surface;

$y$ - the coordinate of the infinitesimal excavated element.

This method is based on Gaussian distribution of the probabilities.

\section{SURFACE SUBSIDENCE PROGNOSIS AT PAROȘENI MINE}

In order to evaluate the deformations of the surface in the Paroseni mining field, Knothe's influence function method was applied to the panels extracted on the coal seams No.3 and 5 after 1990, which are considered to have some influence on the surface (it should be noted that in this mining field 4 panels are extracted from the Vulcan mine). Thus, the area of interest was delimited (Fig. 3), and by applying the aforementioned influence function and joining the subsidence trough associated with each panel (using the Excel and AutoCAD software), we obtained a common subsidence trough, 3D image of which is shown in Fig. 4.

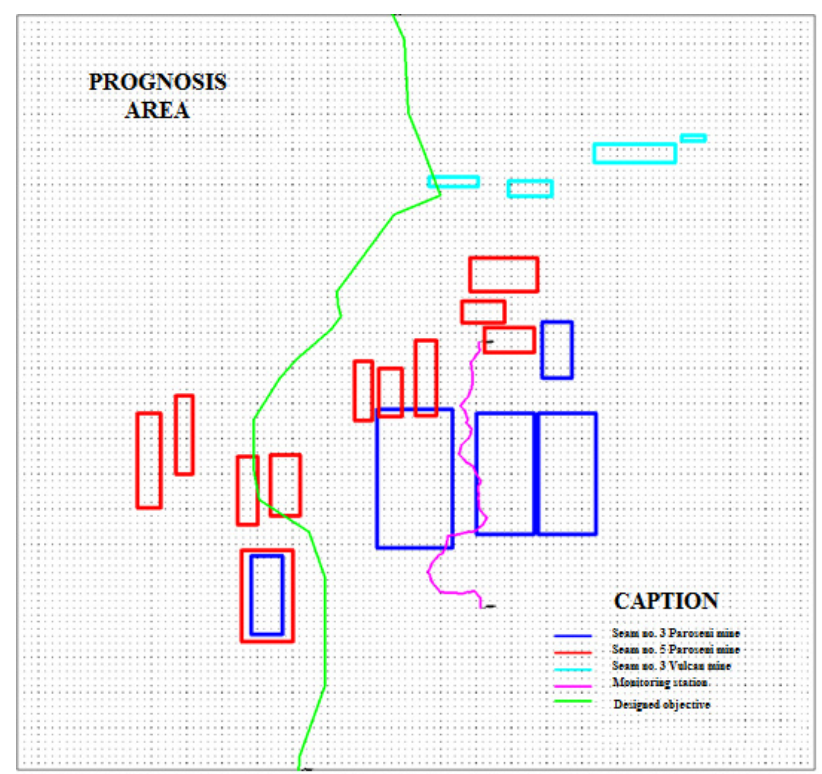

Figure 3. Prognosis of surface subsidence in the case of Paroseni mine

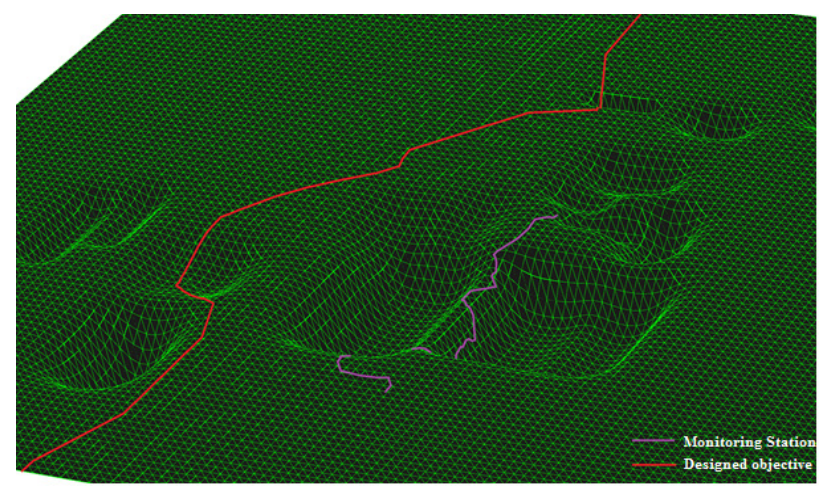

Figure 4. Predicted subsidence trough at Paroseni mine

At the end of 2009, a monitoring station was situated in the area, but since it was done after the start of the underground mining, a large part of the surface movement was not recorded. It is also considered that the predicted subsidence trough is the final one.

In Figure 5 is the curve of predicted subsidence and the measured subsidence on 05.12.2015 in the monitoring station.

Figure 4 represents the location of the proposed object. 


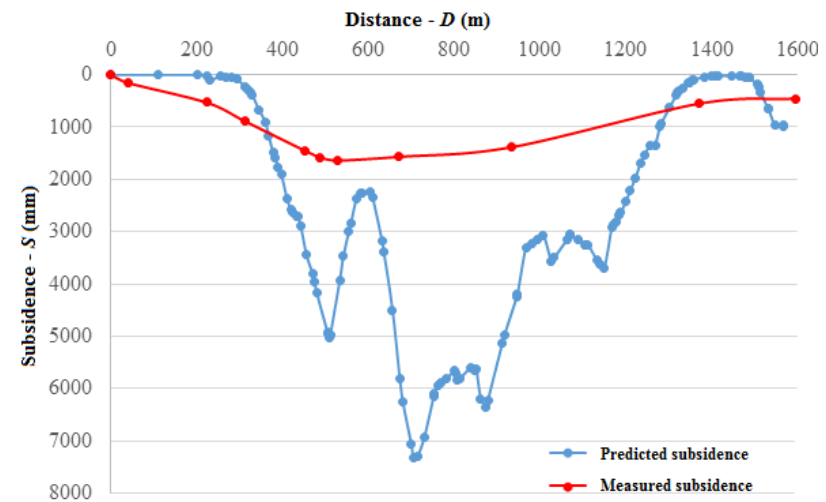

Figure 5. Predicted and measured subsidence curves

As can be seen (both in Figure 4 and in the graph presented in Figure 6) this object was not projected on a stable route and may suffer from subsidence of about $3 \mathrm{~m}$.

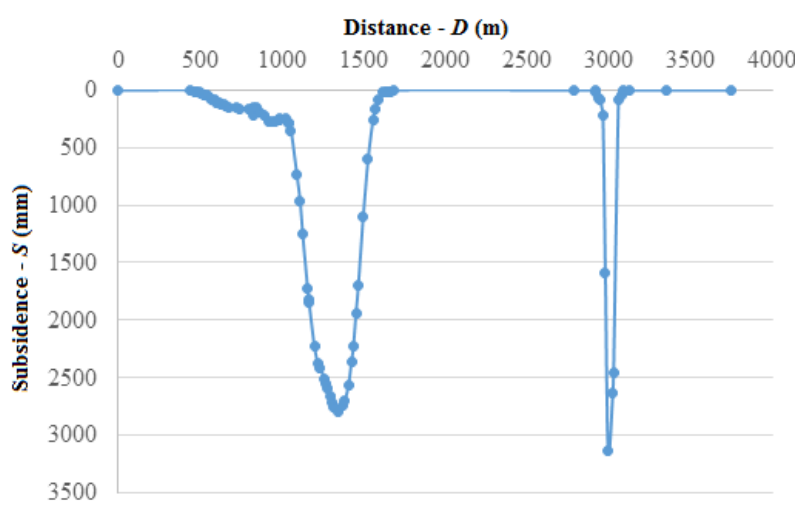

Figure 6. Predicted subsidence curves on the route of the projected object

An important parameter related to the stability of the surface and of the objects located in the area is the horizontal displacement (after the two directions $X$ and $Y$ ), which is graphically represented in Figures $7-10$.

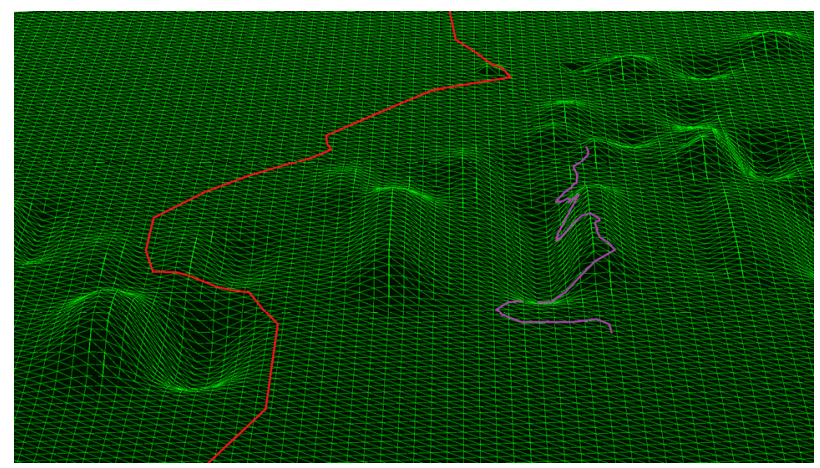

Figure 7. Predicted horizontal displacement after $X$ axis

As can be seen from the horizontal displacement graphs, the surface undergoes significant displacements in both directions due to the numerous panels under study. By evaluating the predicted horizontal displacements for the originally designed object, we can see that it can suffer transversal horizontal displacements of about $1 \mathrm{~m}(+300 \ldots-600 \mathrm{~mm})$ and longitudinal horizontal displacements of approx. $2 \mathrm{~m}(+1500 \ldots-1500 \mathrm{~mm})$. (a)

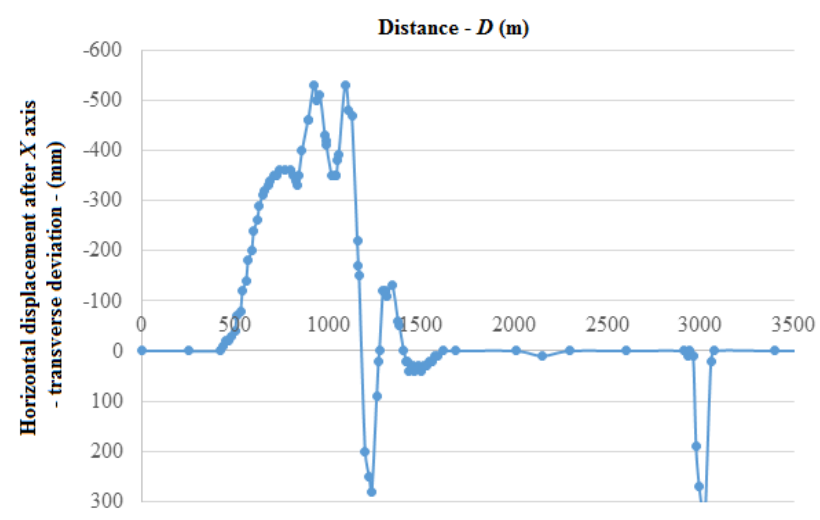

(b)

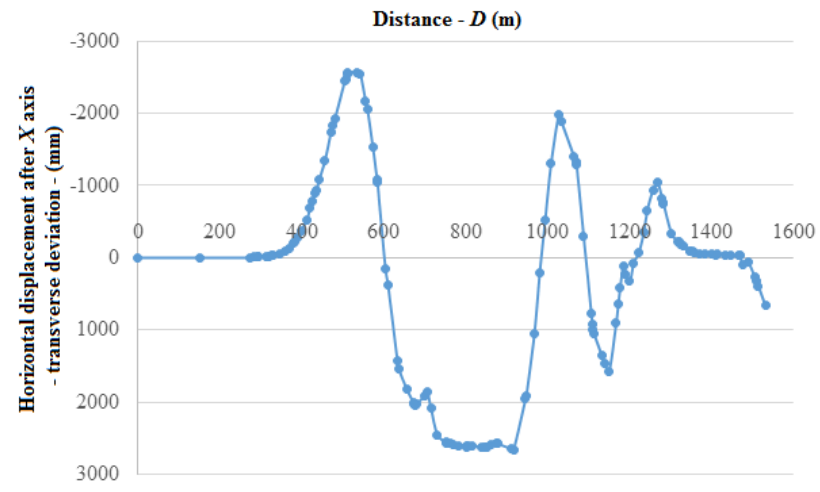

Figure 8. Predicted horizontal displacement after $X$ axis: (a) on the route of the projected object; (b) on the route of the monitoring station

For these reasons, the originally designed route cannot be safe from the point of view of stability and it is recommended to deviate it to a more stable area.

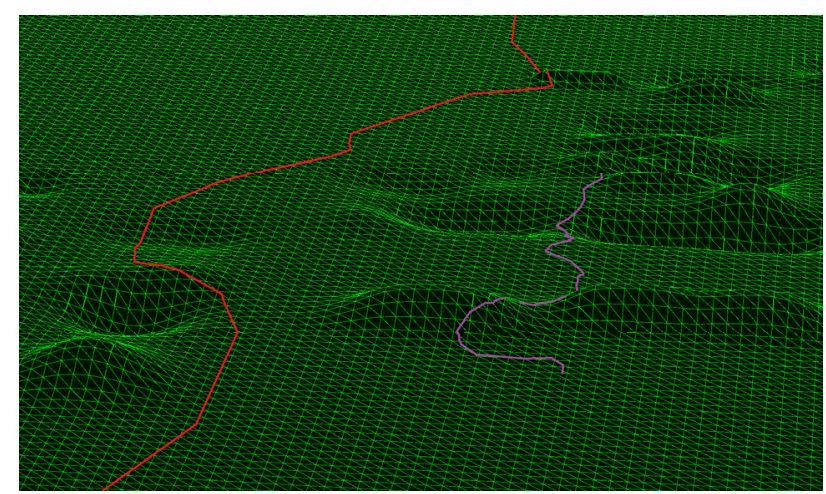

Figure 9. Predicted horizontal displacement after $Y$ axis

\section{CONCLUSIONS}

The influence function method belongs to the empirical methods group applied for the prognosis of the surface deformation due to underground mining. Unlike the profile function method, this method can be applied and operated in the case of several extraction areas, or in the case of the areas with difficult extraction configurations.

By applying the influence function method to the case of the present research, we obtained an overview of the surface deformation as a result of underground mining at Paroseni mine (Jiu Valley, Romania). 
(a)

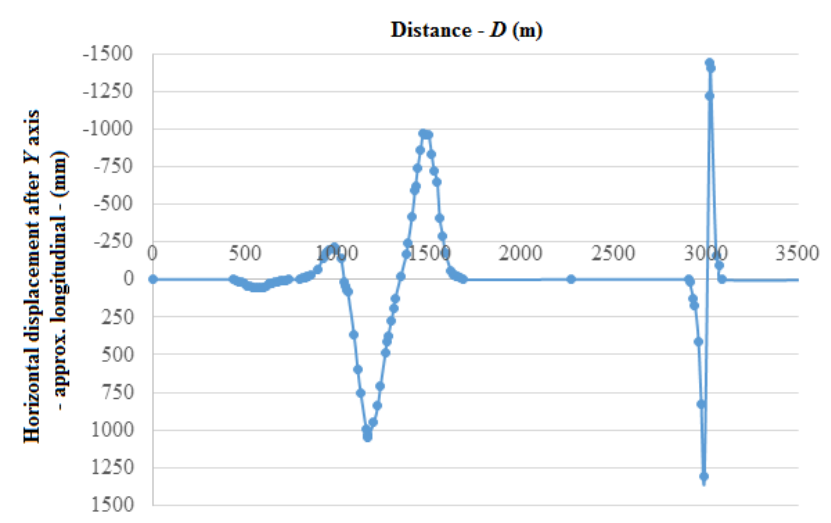

(b)

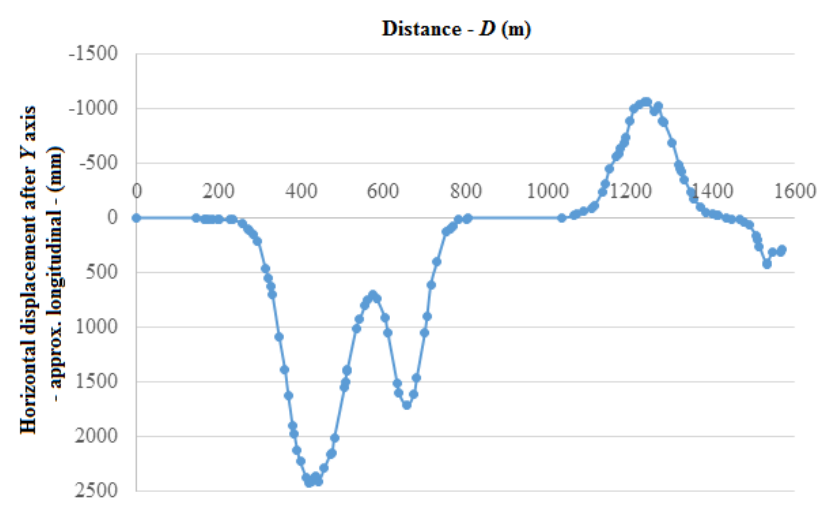

Figure 10. Predicted horizontal displacement after $Y$ axis: (a) on the route of the projected object; (b) on the route of the monitoring station

Following this analysis, it has been observed that the surface suffers major deformations caused by the underground mining both vertically (in the form of subsidence) and horizontally (as horizontal displacement).

By comparing the results obtained by applying the influence function to those measured at the surface, on the monitoring station, it can be observed (Fig. 5) that the displacements are higher than predicted. This is due to the fact that the monitoring station was placed long after the start of the extraction in the area (thus recording only a part of the movement) and the predicted displacements are considered to be the final ones.

Regarding the stability of the projected object (considered in the paper), its route cannot be realized without being affected in the future (more or less) by the underground mining, so it is recommended to move it to a stable area.

If, despite all the inconveniences, it is decided to place the object in this area, it is advisable to take additional safety measures to prevent both the surface deformations and the stresses generated by these deformations.

\section{ACKNOWLEDGEMENTS}

Thanks to the staff from the geology and surveying office of the Paroseni Mine. We also thank to the management of the University of Petroșani for the logistics provided to us and to Mr. Professor PhD. Mining Eng. Onica Ilie for guidance.

\section{REFERENCES}

Fissgus, K. (2011). Subsidence Engineering in Mining. Petrosani, Romania: Universitas Publishing House.

Floarea, D., Marian, D.P., Onica, I., \& Cozma, E. (2015). Necessity of Following up the Land Surface Deformation for Closed Mining Areas. Proceeding of the $15^{\text {th }}$ International Multidisciplinary Scientific Geo-Conference \& Expo, 2(5). https://doi.org/10.5593/sgem2015/b52/s23.097

Luo, Y., Peng, S., \& Zhu, Z. (2008). Upgraded Comprehensive and Integrated Subsidence Prediction Model CISPM. Morgantown, West Virginia, United States: West Virginia University.

Marian, D.P. (2011). Surface Stability Analysis as Effect of Underground Mining of the Coal Seams with Gentle and Medium Dip from the Jiu Valley Coal Basin. PhD. Petrosani, Romania: University of Petrosani.

Marian, D.P., Onica, I., Marian, R.R., \& Floarea, D. (2017). Surface Subsidence Prognosis Using the Influence Function Method in the Case of Livezeni Mine. Mining Revue, 23(1), 9-14.

Onica, I., \& Marian, D.P. (2012). Ground Surface Subsidence as Effect of Underground Mining of the Thick Coal Seams in the Jiu Valley Basin. Archives of Mining Sciences, 57(3), 547-577. https://doi.org/10.2478/v10267-012-0036-z

Onica, I., Cozma, E., Marian, D.P., \& Ştefan, N. (2014). Prognosis of the Maximum Subsidence and Displacement of the Ground Surface in the Jiu Valley Coal Basin. Proceeding of the $14^{\text {th }}$ International Multidisciplinary Scientific GeoConference \& Expo, 3(1), 465-472. https://doi.org/10.5593/sgem2014/b13/s3.061

Ortelecan, M. (1997). The Study of Ground Surface Displacement Under the Underground Mining of Jiu Valley Coal Deposits - Eastern Zone. Ph.D. Petrosani, Romania: University of Petrosani.

Taherynia, M.H., Fatemi Aghda, S.M., Ghazifard, A., \& Mordi, E. (2017). Prediction of Subsidence Over Oil and Gas Fields with Use of Influence Functions (Case Study: South Pars Gas Field, Iran). Iranian Journal of Science and Technology, Transactions A: Science, 41(2), 375-381. https://doi.org/10.1007/s40995-016-0037-4

Vereș, I., Marian, D.P., Fissgus, K., \& Ștefan, N. (2017). Finite Element Analysis of Surface Subsidence for Establishing the Location of a Gas Pipeline. In Modern Technologies for the $3^{\text {rd }}$ Millennium (pp. 297-302). Oradea, Romania: Editografica.

Wei, W., Lu, T.H., Sun, B.X., \& Wei, L.L. (2007). A Mathematic Model of Time-Dependent Subsidence of Coal Mining Work-Out Area. In International Conference on Mine Hazards Prevention and Control. Qingdao, China: College of Resources and Environmental Engineering, Shandong University of Science and Technology.

Zhu, X., Guo, G., Zha, J., Chen, T., Fang, Q., \& Yang, X. (2016). Surface Dynamic Subsidence Prediction Model of Solid Backfill Mining. Environmental Earth Sciences, 75(12), 1007. https://doi.org/10.1007/s12665-016-5817-9

\section{ПРОГНОЗУВАННЯ ДЕФОРМАЦЇ̈ ЗЕМНОЇ ПОВЕРХНІ МЕТОДОМ ФУНКЦІЇ ВПЛИВУ НА ПРИКЛАДІ ШАХТИ ПАРОСЕНІ (РУМУНІЯ)}

\section{Р.Р. Маріан, Д.П. Маріан}

Мета. Прогнозування деформації земної поверхні в результаті підземної розробки похилих вугільних пластів у межах гірничого відводу шахти Паросені (Румунія) методом функції впливу. 
Методика. Для оцінки деформації поверхні в околиці шахти Паросені використано метод функцій впливу Кноте, який застосовано до відпрацьованих панелей вугільних пластів №3 і 5, а також моніторингові спостереження поверхневою станцією. Область, що представляє науковий інтерес, була виділена із застосуванням методу функції впливу та шляхом об'єднання воронки опускання, пов'язаної з кожної панеллю за допомогою програмного забезпечення Excel, AutoCAD і спрогнозована у 3D-зображенні.

Результати. Встановлено, що поверхня, де проектується промисловий об'єкт у районі гірничого відводу шахти, зазнає значних зсувів в обох напрямках $X$ та $Y$, що пов'язано зі значним числом досліджуваних панелей. В результаті оцінки прогнозованих горизонтальних зсувів для проектованого об'єкта очевидно, що він може піддаватися поперечним горизонтальним зміщенням близько 1 м і поздовжнім горизонтальним зміщенням близько 2 м, тому поверхня не $є$ безпечною з точки зору стійкості, а закладення об'єкта рекомендується змістити до більш стабільної області. Порівняння результатів, отриманих за допомогою функції впливу, з виміряними на поверхні шляхом станції моніторингу, показало, що зміщення вище, ніж прогнозувалося, і пов'язане 3 тим, що станція моніторингу була розміщена задовго до початку видобутку в цій області.

Наукова новизна. Вперше для гірничо-геологічних умов розробки вугільних пластів шахти Паросені виконано прогнозування та оцінку деформацій земної поверхні методом функції впливу, який є відомим і широко застосовуваним методом при дослідженні явища осідання.

Практична значимість. Отримані результати дають можливість спрогнозувати вплив підземної розробки корисних копалин на поверхню, а саме, з достатньою точність визначити обсяг деформованої поверхні та розташування важливих об’єктів у зоні розробки з метою подальшого прийняття відповідних заходів для захисту уже існуючих об'єктів і об'єктів, які будуть побудовані.

Ключові слова: підземна розробка, вугільні пласти, прогнозування, функція впливу, осідання, горизонтальні зміщення

\section{ПРОГНОЗИРОВАНИЕ ДЕФОРМАЦИИ ЗЕМНОЙ ПОВЕРХНОСТИ МЕТОДОМ ФУНКЦИИ ВЛИЯНИЯ НА ПРИМЕРЕ ШАХТЫ ПАРОСЕНИ (РУМЫНИЯ)}

\section{Р.Р. Мариан, Д.П. Мариан}

Цель. Прогнозирование деформации земной поверхности в результате подземной разработки наклонных угольных пластов в пределах горного отвода шахты Паросени (Румыния) методом функции влияния.

Методика. Для оценки деформации поверхности в окрестности шахты Паросени использован метод функций влияния Кнота, который применен к отработанным панелям угольных пластов №3 и 5, а также мониторинговые наблюдения поверхностной станцией. Представляющая научный интерес область была ограничена с применением метода функции влияния и посредством объединения воронки опускания, связанной с каждой панелью, при помощи программного обеспечения Excel, AutoCAD и спрогнозирована в 3D-изображении.

Результаты. Установлено, что поверхность, где проектируется промышленный объект в районе горного отвода шахты, подвергается значительным смещениям в обоих направлениях $X$ и $Y$, что связано со значительным числом исследуемых панелей. В результате оценки спрогнозированных горизонтальных смещений для проектируемого объекта очевидно, что он может подвергаться поперечным горизонтальным смещениям около 1 м и продольным горизонтальным смещениям порядка 2 м, поэтому поверхность не является безопасной с точки зрения устойчивости, а заложение объекта рекомендуется сместить до более стабильной области. Сравнение результатов, полученных с помощью функции влияния, с измеренными на поверхности посредством станции мониторинга, показало, что смещение выше, чем прогнозировалось, и связано с тем, что станция мониторинга была размещена задолго до начала добычи в этой области.

Научная новизна. Впервые для горно-геологических условий разработки угольных пластов шахты Паросени выполнено прогнозирование и оценка деформаций земной поверхности методом функции влияния, являющийся известным и широко применяемым методом при исследовании явления оседания.

Практическая значимость. Полученные результаты дают возможность спрогнозировать влияние подземной разработки полезных ископаемых на поверхность, а именно, с достаточной точность определить объем деформированной поверхности и расположение важных объектов в зоне разработки с целью последующего принятия соответствующих мер для защиты уже существующих объектов и объектов, которые будут построены.

Ключевые слова: подземная разработка, угольные пласты, прогнозирование, функция влияния, оседание, горизонтальные смещения

\section{ARTICLE INFO}

Received: 8 December 2017

Accepted: 26 March 2018

Available online: 31 March 2018

\section{ABOUT AUTHORS}

Ramona-Rafila Marian, PhD Student of the Department of Mining Engineering, Surveying and Civil Engineering, University of Petrosani, 20 University St, 332006, Petrosani, Romania. E-mail: ramona nicolae4@yahoo.com

Dacian-Paul Marian, Senior Lecturer of the Department of Mining Engineering, Surveying and Civil Engineering, University of Petrosani, 20 University St, 332006, Petrosani, Romania. E-mail: dacianmarian@upet.ro 